\title{
Another family with the 'Habsburg jaw'
}

E M THOMPSON* AND R M WINTER $\dagger$

From ${ }^{*}$ the Department of Paediatric Genetics, Institute of Child Health, 30 Guilford Street, London WC1N 1EH; and the Kennedy-Galton Centre, Clinical Research Centre, Northwick Park Hospital, Watford Road, Harrow, Middlesex HAl $3 H J$.

SUMMARY We report a three generation family with similar facial characteristics to those of the Royal Habsburgs, including mandibular prognathism, thickened lower lip, prominent, often misshapen nose, flat malar areas, and mildly everted lower eyelids. One child had craniosynostosis which may be part of the syndrome.

The Habsburgs, one of Europe's foremost royal families, are famous not only for the duration of their reign and brilliance of their leadership, but also because they represent one of the few examples of Mendelian inheritance of facial characteristics. This has been referred to as the 'Habsburg jaw' to describe the prognathic mandible which was seen in

Received for publication 9 December 1987

Revised version accepted for publication 2 March 1988.

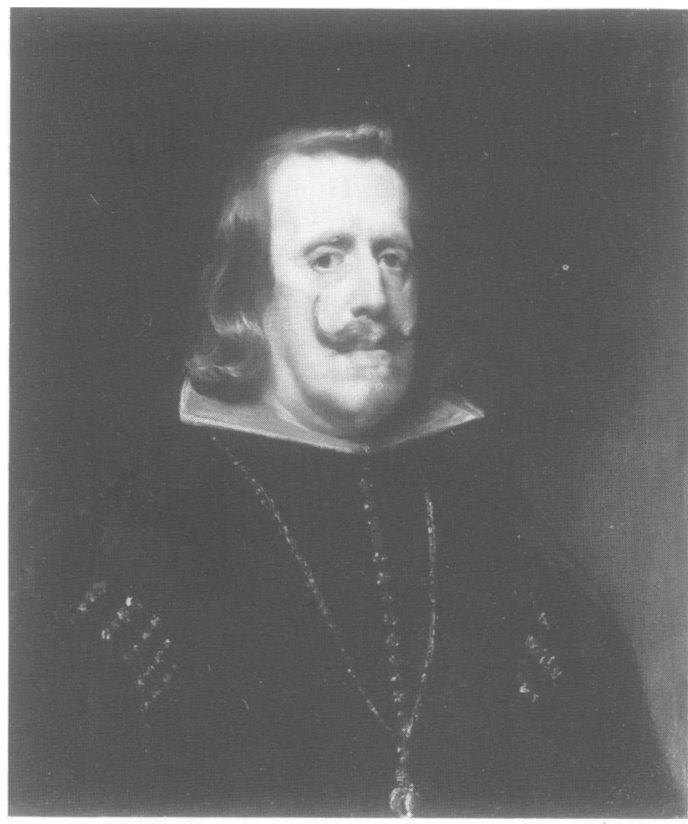

FIG 1 Philip IV by Velázquez. Note the prognathic mandible, prominent nose with a dorsal hump, thickened lower lip, flat malar areas, and mildly everted lower eyelids. (Reproduced with permission from the National Gallery, London.) nine successive generations of the family ${ }^{1}$ (fig 1). Although it was transmitted as an autosomal dominant trait, males were more severely affected than females. Examination of the abundant portraits of the family shows, in addition to prognathism, a thick, everted lower lip, a large, often misshar ?n nose with a prominent dorsal hump, a tendency to flattening of the malar areas, and mild eversior of

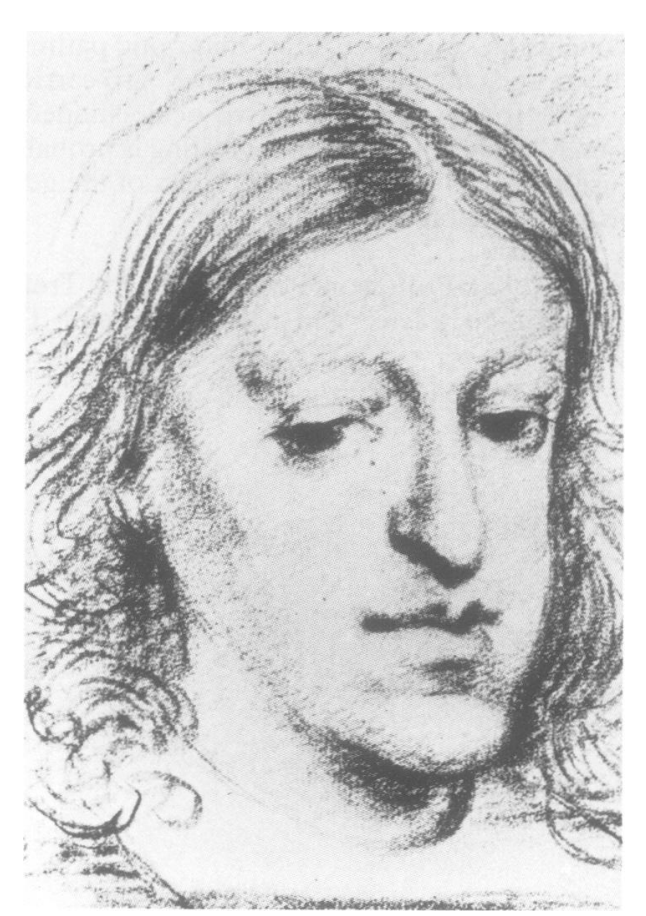

FIG 2 Carlos II by Carreño de Miranda. Note the prominent mandible, everted lower lip, malar flattening, and mild lower eyelideversion. (Reproduced with permission from the Academy of San Fernando, Madrid.) 
the lower eyelids (figs 1 and 2). Perhaps the most severely affected was the Holy Roman Emperor, Charles V of Spain, who had a massive jaw and severe dental malocclusion (fig 3). He suffered severely in consequence. His jaw caused his mouth

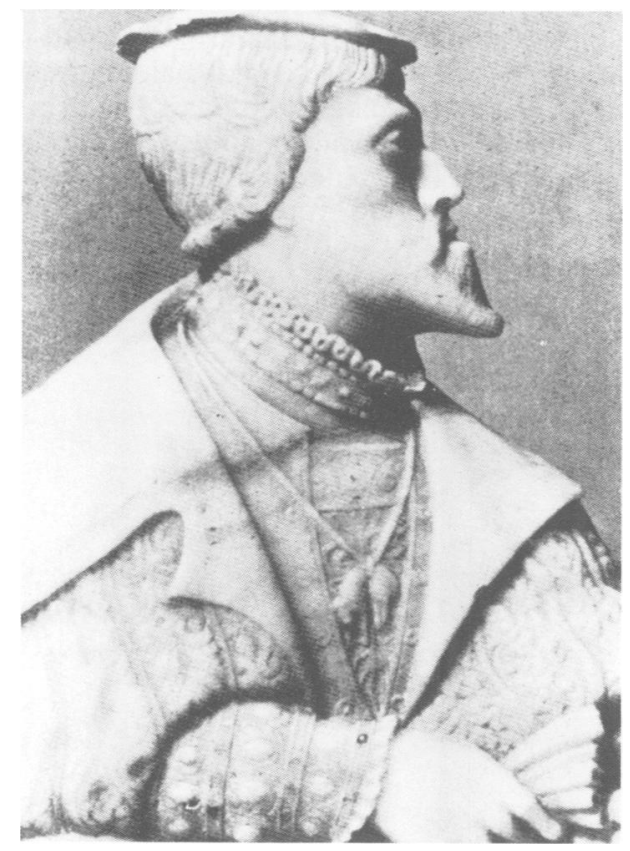

FIG 3 King Charles V: sculpture by Joachim Dreschler. Note the severemandibularprognathism and malocclusion, the flat malar areas, and a rather sloping forehead.

(Reproduced with permission from the Kunsthistorisches Museum, Vienna.)

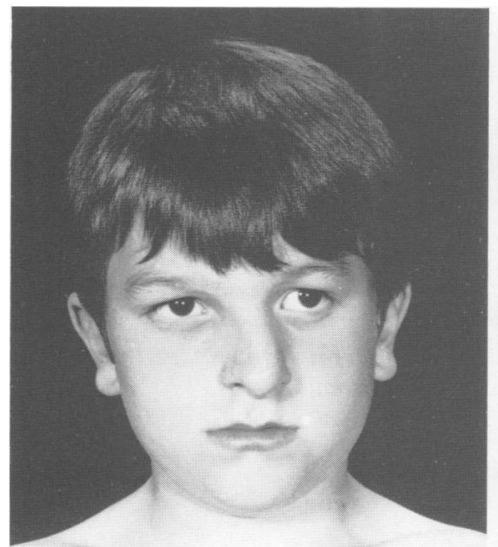

to hang open and interfered with his speech, and it is said that when he first came to Spain from Ghent a Spanish peasant shouted to him "Your Majesty, shut your mouth, the flies of this country are very insolent". (Quoted in Grabb et $a l^{2}$ from LangdonDavies. $\left.^{3}\right)$

The Habsburgs suffered from various other ailments including asthma, gout, dropsy, epilepsy, and melancholia. ${ }^{4}$ Although it is true that consanguinity was common in the family and may have contributed to some of these disorders, it is unlikely to account for the dominant 'Habsburg jaw' trait, as was suggested previously. ${ }^{2}$ However, as seen in the pedigree shown by Rubbrecht, ${ }^{5}$ in some instances a consanguineous marriage resulted in two affected persons marrying. For example, Marie d'Autriche married her cousin Maximilien II; both had marked prognathism and all of their eight children were said to be affected, some severely so. ${ }^{1}$ Whether the very severely affected Charles V, mentioned above, represents a homozygote for the gene is uncertain. Rubbrecht ${ }^{1}$ considered that his mother Jeanne la Folle was affected but concluded that it was difficult to make the diagnosis in his father Philippe le Beau, who himself had an affected father.

Genetic studies on mandibular prognathism are few. ${ }^{5-7}$ Generally they conclude that it may be inherited as an autosomal dominant trait with reduced penetrance. McKusick (No 17670$)^{8}$ has observed a dominant inheritance pattern in a black family.

\section{Case reports}

A family was referred to the genetic clinic because

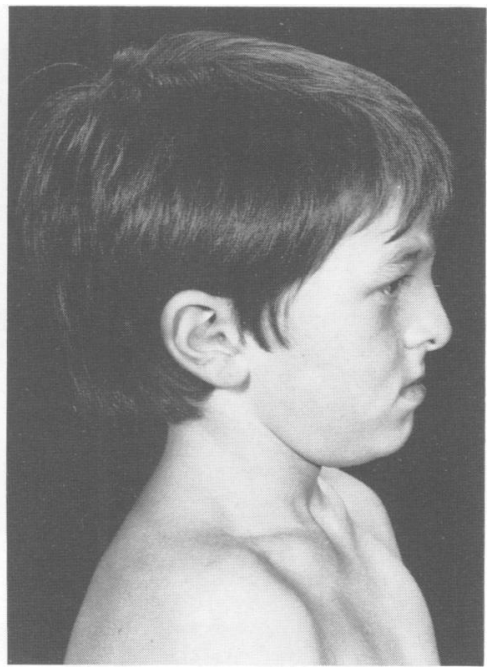

FIG 4 Theolderbrother. Note the mandibularprognathism, thickened lowerlip, prominent and misshapen nose, and maxillary hypoplasia. 
of an unusual facial appearance in two brothers, their father, and their paternal grandmother.

The brothers were aged seven and six years at the time of examination. Both were born at term after a normal pregnancy and delivery, weighing $4451 \mathrm{~g}$ and $4082 \mathrm{~g}$ at birth respectively. The neonatal period was normal, but an oxycephalic skull shape was noted in the younger child from birth and this had become more obvious recently. Both children have suffered from recurrent middle ear infections and had tonsillectomies, adenoidectomies, and insertion of drainage tubes into the middle ears. The younger boy had severe chronic nasal congestion. Intelligence was normal but both children had suffered considerable teasing at school because of their facial appearance. The older child (fig 4) had marked maxillary hypoplasia, mandibular prognathism, and a misshapen nose, while the younger had oxycephaly and a rather prominent nose, but no marked mid-face hypoplasia (fig 5). Both had dental malocclusion, of greater degree in the older child (class III) than the younger (class I). Vision and hearing were normal in both children. The older boy had no ocular abnormalities, but the younger had mild right

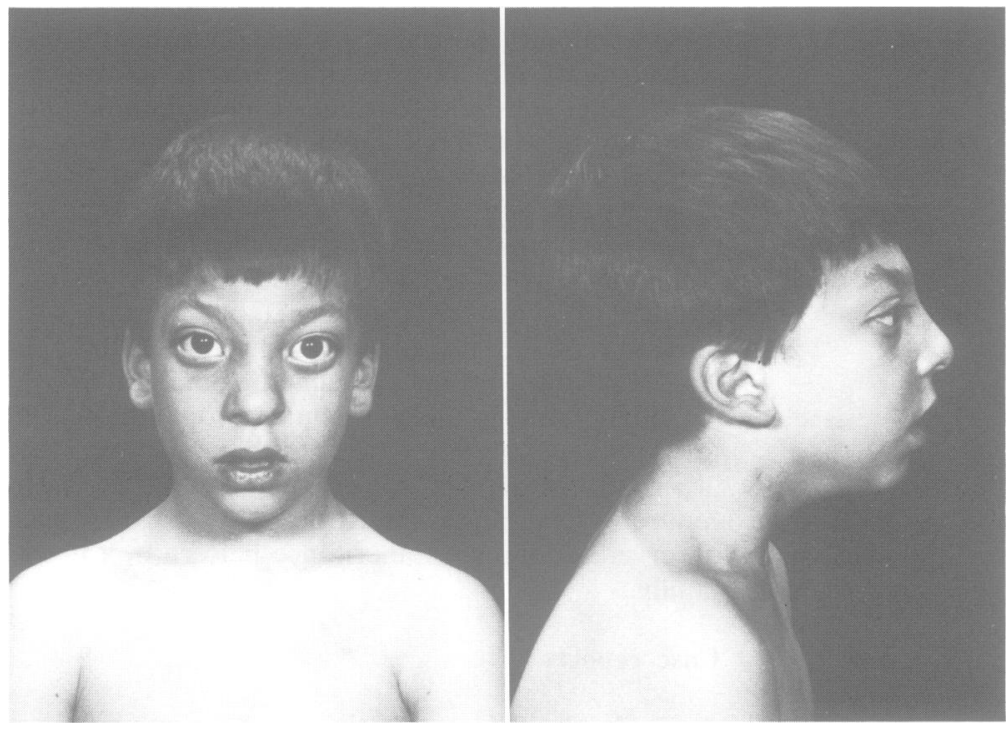

FIG5 Theyoungerbrother. Note theprominent noseand oxycephalicskullshape.
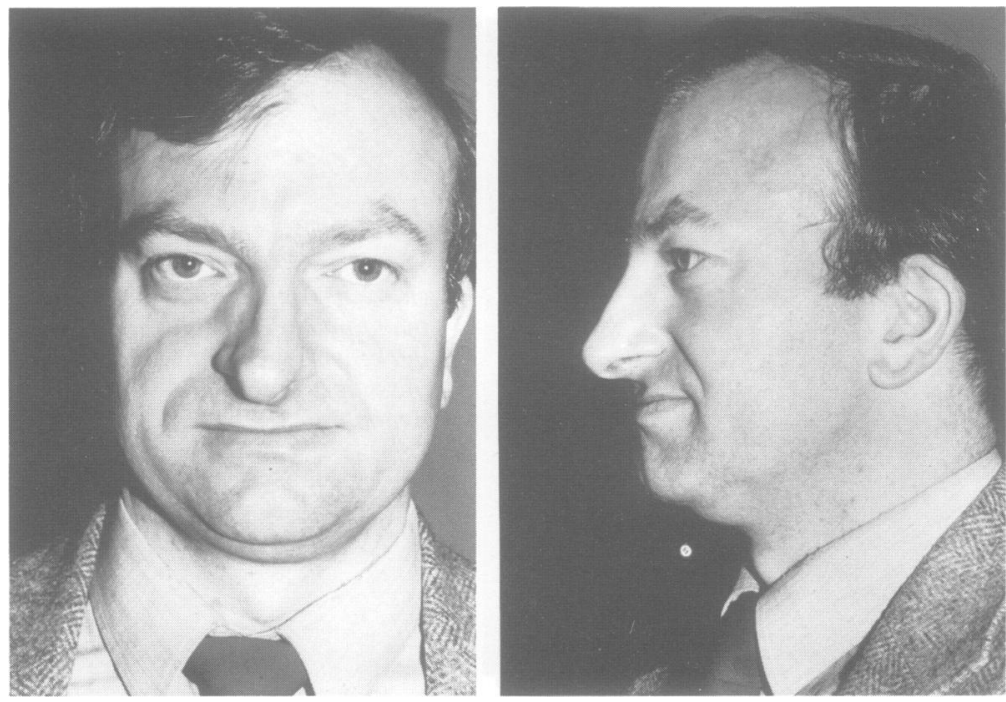

FIG 6 The father. Note the prominent jaw, misshapennose, and flatmalarareas. 

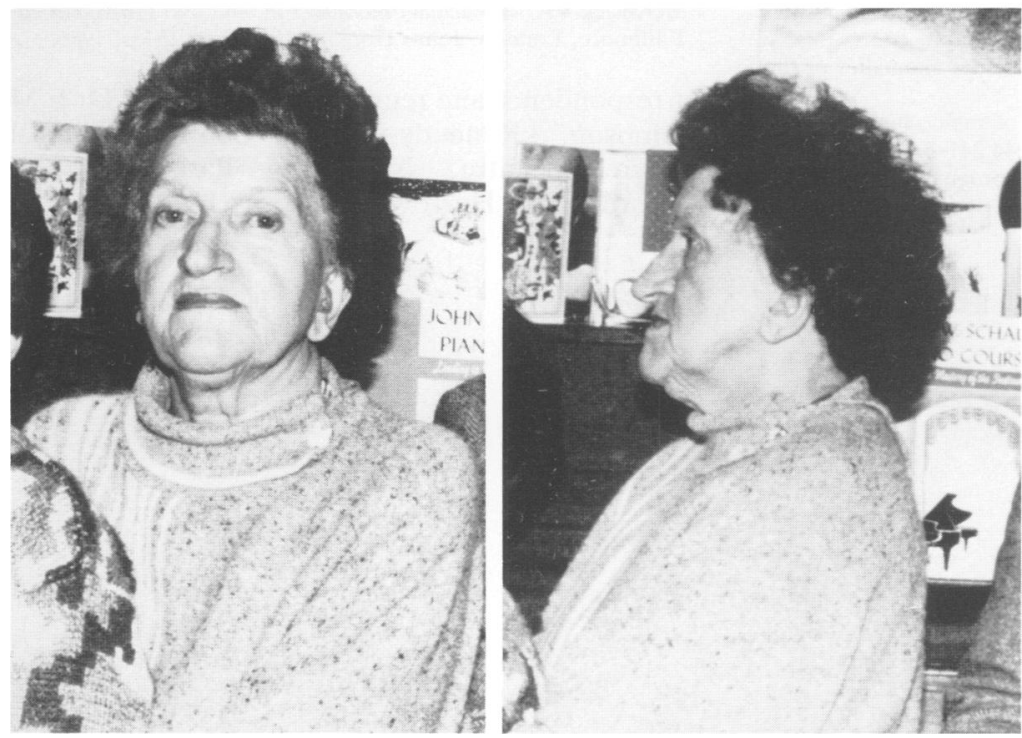

FIG 7 The father's mother. The features are similar to the other affected family members, including mild lower eyelid eversion. papilloedema, mild bilateral proptosis, and limitation of elevation of the left eye on abduction. Examination of the extremities showed that the brothers had large halluces with mild syndactyly between the second and third toes bilaterally in the older boy.

Skull $x$ rays showed a normal vault in the older child but synostosis of all cranial sutures with digital markings over the skull vault in the younger.

Subsequently, surgical procedures were undertaken on both children, namely surgical advancement of the mid-face in the older boy and correction of oxycephaly (realignment of the supraorbital ridges and frontal bones) in the younger, with good results.

The father, a 40 year old actor, had a similar facial appearance to his sons with maxillary hypoplasia, mandibular prognathism, and a misshapen nose (fig 6). He gave a history of having an eye operation at the age of three years for a squint and of chronic nasal congestion. He had normal hearing and a normal skull vault on $x$ ray. The halluces were large and there was bilateral skin syndactyly between the second and third toes.

The father's mother was not seen personally by the authors but a photograph of her (fig 7) showed a similar facial appearance to that of her son. She had a greater degree of mandibular prognathism compared to her other affected relatives and bore the closest resemblance to the Habsburgs.

\section{Discussion}

These sibs, their father, and their maternal grand- mother bear a striking resemblance to members of the Habsburg family with the Habsburg jaw. The features include mandibular prognathism, a thickened, everted lower lip, a prominent, often misshapen nose, maxillary hypoplasia, and mild eversion of the lower eyelids. In this family, intellect was normal and general health was good, apart from symptoms of upper respiratory tract obstruction which could have resulted from nasal deformity. The presence of various other disorders in the Habsburg lineage were probably separate from the gene which caused the characteristic facies.

The prognathism was less marked in the younger child, but interestingly his oxycephalic head shape is similar to that of Charles V (fig 3). Perhaps Charles $\mathrm{V}$ may also have had a degree of craniosynostosis.

As far as can be determined this family is not related to the Habsburg line. Although other reports of dominantly inherited prognathism exist, this is perhaps the first reported example of the complete 'Habsburg facies' outside the royal dynasty.

We are grateful to Mr B M Jones, Consultant Plastic and Reconstructive Surgeon, and $\mathrm{Dr}$ Michael Baraitser, Consultant Geneticist, for permission to report their patients. We thank Miss Jo Bramfitt for typing the manuscript.

\section{References}

${ }^{1}$ Rubbrecht $O$. La prognathie inférieure dans la maison de Habsbourg et l'hérédité. Rev Belge Stomatol 1930;27:175-211.

2 Grabb WC, Hodge GP, Dingman RO, O'Neal RM. The Habsburg jaw. Plast Reconstr Surg 1968;42:442-5.

${ }^{3}$ Langdon-Davies J. Carlos, the king who would not die. Englewood Cliffs, NJ: Prentice-Hall, 1963:21. 
${ }^{4}$ Hodge GP. A medical history of the Spanish Habsburgs. JAMA 1977;238:1169-74.

5 Rubbrecht $\mathrm{O}$. A study of the heredity of the anomalies of the jaws. Am J Orthodont 1939;25:751-79.

6 Stiles KA, Luke JE. The inheritance of malocclusion due to mandibular prognathism. J Hered 1953;44:241-5.

7 Schulze C, Weise W. The heredity of prognathism. Fortschr Kieferorthop 1965;26:213-29.
${ }^{8}$ McKusick VA. Mendelian inheritance in man. No 17670.7 th ed. Baltimore, London: Johns Hopkins University Press, 1986.

Correspondence and requests for reprints to Dr E M Thompson, Kennedy-Galton Centre, Clinical Research Centre, Northwick Park Hospital, Watford Road, Harrow, Middlesex HA1 3UJ. 